\title{
MANITOBA'S SOUTHERN BIRD INVASION, MAY 2006
}

CHRISTIAN ARTUSO, Dept. of Environment and Geography, University of Manitoba, Winnipeg, MB R2T 2N2. E-mail: chartuso@gmail.com

May 2006 was an exceptional month for birding in Manitoba, with a string of southern rarities that produced no fewer than three provincial firsts (if accepted): Swainson's Warbler, Black Vulture, and Broad-tailed Hummingbird. The majority of these southern rarities were Neotropical migrants with predominantly Carolinian or southern temperate breeding distributions, whose nearest breeding grounds average $700 \mathrm{~km}$ south-southeast of Manitoba. Several species that breed in western North America, but are either very rare in Manitoba or irruptive, were also recorded, including an immature Whooping Crane that remained in the
St. Adolphe area for at least a month. Details of the provincial firsts are provided in Table 1, and other accidental and noteworthy species are summarized in Table 2.

First Records in Manitoba

In the second week of May, two species which had not previously been recorded in Manitoba, Swainson's Warbler and Black Vulture, were each photographed approximately $2000 \mathrm{~km}$ north of their nearest breeding grounds. ${ }^{1,4}$ The Swainson's Warbler was found in river bottom forest of Beaudry Provincial Park, just west of Winnipeg, on May 8 (Figure 1). An

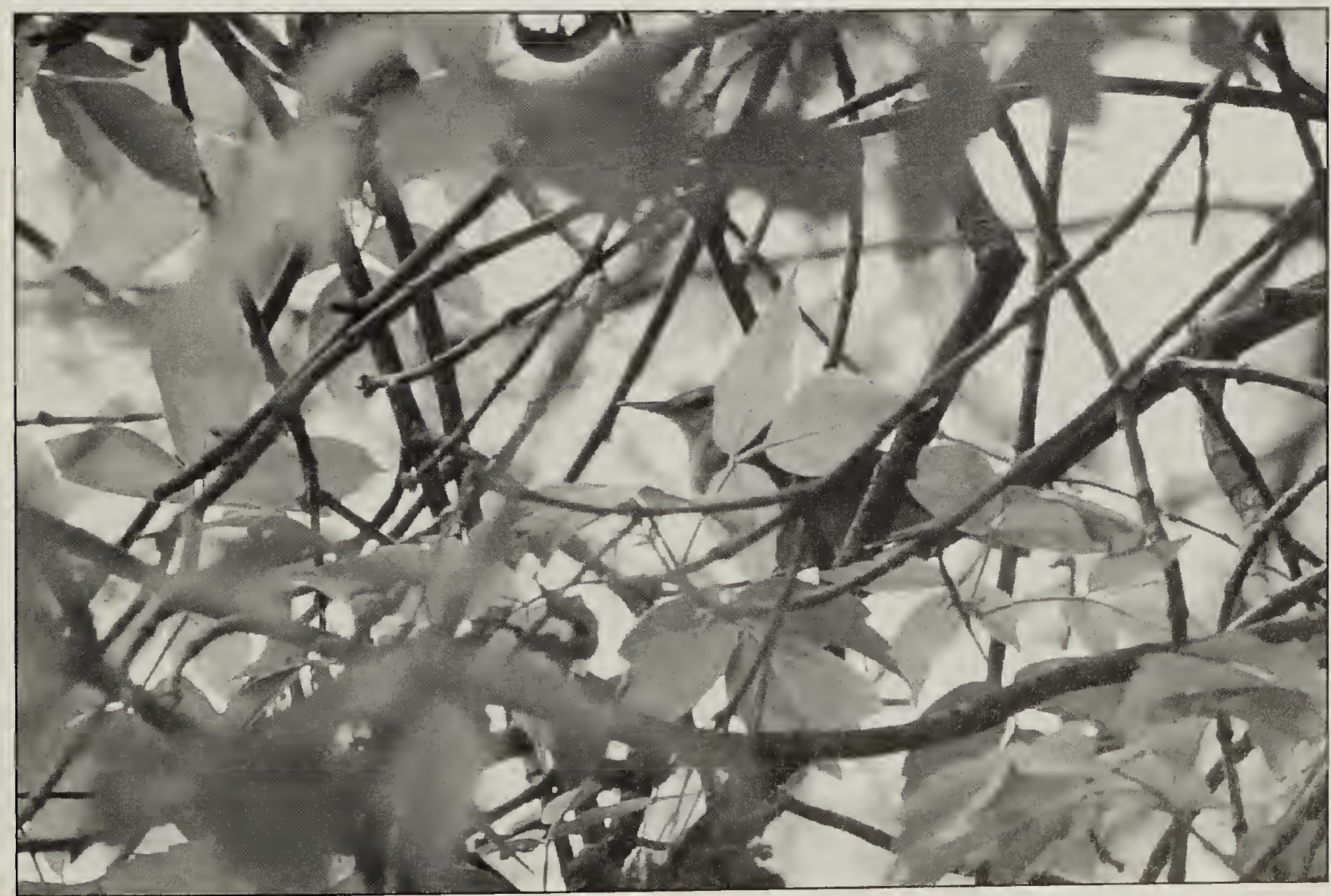

Figure 1. Swainson's Warbler in Beaudry Provincial Park on May 8, 2006.

Christian Artuso 
indication of the extraordinary nature of this record is that there are no accepted reports of Swainson's Warbler in Minnesota (Kim Eckert, pers. comm.). This appears to be the first sighting in western Canada of this skulking species. There are eight accepted Canadian records - seven from Ontario, ${ }^{7}$ and one from Nova Scotia. ${ }^{8}$ Interestingly, a single observer reported a Swainson's Warbler in Toronto on May 12, 2006 (Mount Pleasant Cemetery, Attila Fust), only three days after the Manitoba record. This has not yet been reviewed by the Ontario Bird Records Committee.

The Black Vulture was photographed in Wanless, $37 \mathrm{~km}$ north of The Pas, on May 11 (Figure 2) and the photo was posted on the Manitoba Naturalists Society web page as an identification query. Although this is the first record in

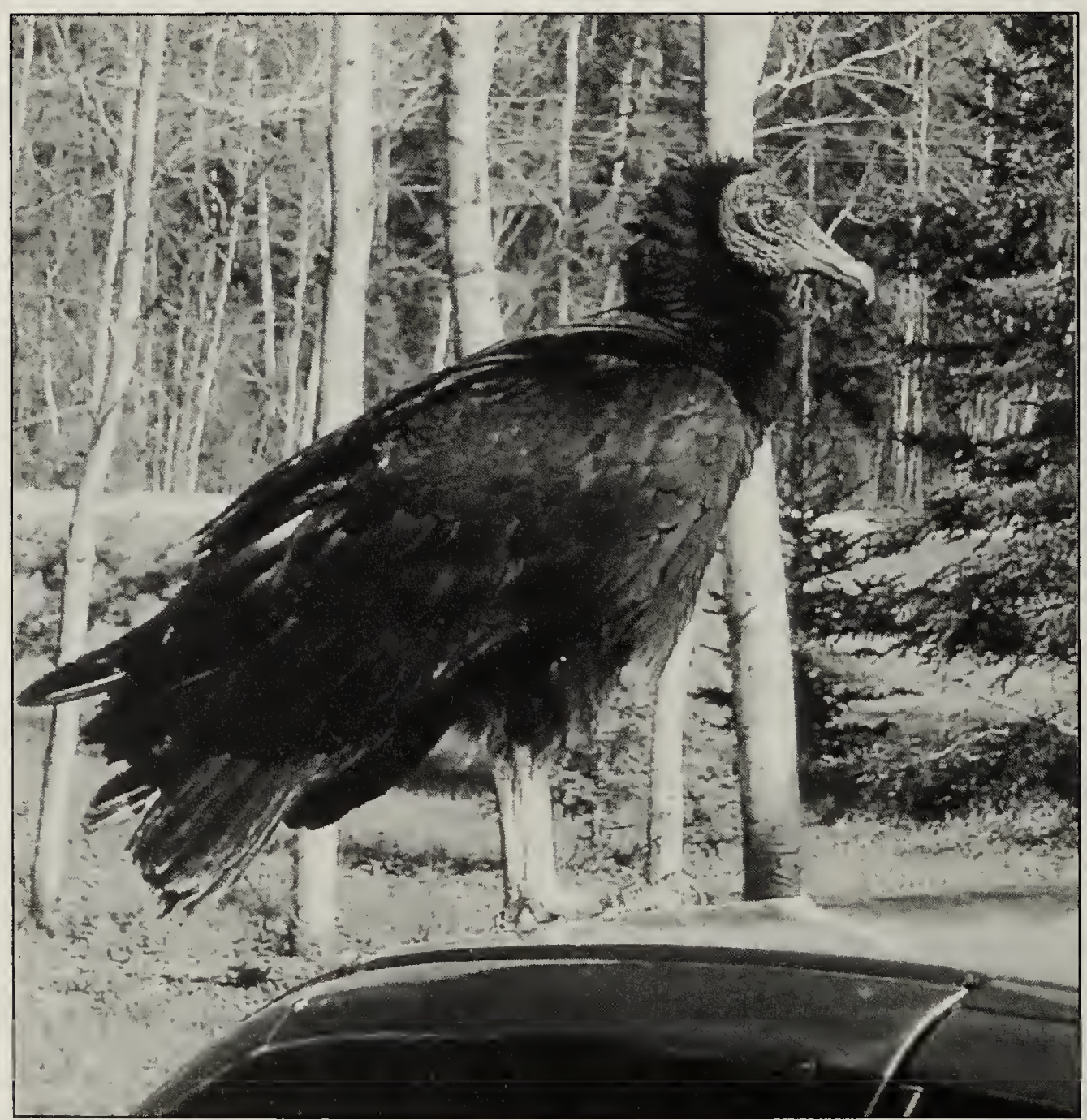

Figure 2. Black Vulture in Wanless on May 11, 2006

Rita Beecham.
Manitoba, this species has a history of vagrancy in eastern Canada, ${ }^{9}$ with 50 accepted records in Ontario, ${ }^{7}$ and several records in western Canada, including one at Fort Qu'Appelle, Saskatchewan on 25 May 1992,15 and one photographed at Kluane Lake, Yukon on July 2, $1982 .{ }^{8}$ There are three accepted records in Minnesota (August 28, 2001 in Duluth; April 29, 2003 in Duluth; and May 26, 2004 near Two Harbours) (Anthony Hertzel, pers. comm.). The only record from North Dakota involves two birds shot near Sanborn in September 1892. ${ }^{3}$

On May 16, a male Broad-tailed Hummingbird visited a feeder in Portage la Prairie and remained in the area for approximately two weeks, attracting birders from as far afield as Ontario and British Columbia (see back cover and inside front cover photographs). This is the first record for the prairie provinces and only the third in Canada; the two previous ones were July sightings of adult males in British Columbia. ${ }^{6}$ There are no records from Minnesota (Anthony Hertzel, pers. comm.) and the only record for North Dakota was a firstyear Selasphorus believed to be this $s$ e c i e s, photographed in Kidder County on September 3, 2006 (not yet reviewed). ${ }^{13}$ 
Table 1. First records in Manitoba in May 2006 with distance to nearest breeding sites as calculated from The Birds of North America accounts (not including areas wherc the species is described as a rare

breeder).

\begin{tabular}{|c|c|c|c|c|}
\hline Species & $\begin{array}{l}\text { Date: } \\
\text { May }\end{array}$ & Location & Nearest breeding & Observer(s) \\
\hline Swainson's Warbler (1) & 08 & Beaudry PP & MO: $1900 \mathrm{~km} \mathrm{SSE}^{1}$ & C. Artuso* \\
\hline Black Vulture (1) & 11 & Wanless & $\begin{array}{l}\text { IN: } 1950 \mathrm{~km} \mathrm{SE} \\
\text { OK: } 2000 \mathrm{~km} \mathrm{SSE}\end{array}$ & D. Beecham* \\
\hline Broad-tailed Hummingbird ( 10 ) & $16-29$ & Portage la Prairie & $W Y: 900 \mathrm{~km} \mathrm{SW}^{5}$ & C. Braden, m.o* \\
\hline
\end{tabular}

\section{Other Accidental and Noteworthy Species}

A male Prothonotary Warbler was present from May $3-6$ at the Fort Whyte Centre (FortWhyte Alive) in Winnipeg, where it was observed feeding low above the water of several small lakes (see inside front cover photograph). This individual may have been present in late April according to the Centre's staff (Leslie Alexander, pers. comm.). There are only five previous records of this species in Manitoba, although only two of the four discussed in The Birds of Manitoba are accepted. ${ }^{11} \mathrm{~A}$ fifth record occurred after the publication of that book, when Brad Carey, Ward Christianson, Larry de March, and Marlene Waldron observed a
Prothonotary Warbler at St. Ambroise Provincial Park on September 11, 2004. Two of the five Manitoba sightings were in May. Four of the seven records from Saskatchewan were in May and three were in the fall. ${ }^{15}$

Another exceptional visitor was an immature Whooping Crane, first recorded on May 10 near St. Adolphe (Figure 3). Discussions with local residents suggest it was present in the first week of May (Greg Buzza, pers. comm.). This bird was unbanded and therefore from the Wood Buffalo flock. It may have found its way to Manitoba after being separated from accompanying adults during migration (Brian Johns, pers. comm.). It remained

Table 2. Other accidental and noteworthy species recorded in Manitoba in May 2006 with the number of previous accepted records from The Birds of Manitoba. ${ }^{11}$

\begin{tabular}{|c|c|c|c|c|}
\hline Species & $\begin{array}{l}\text { Date: } \\
\text { May }\end{array}$ & Location & $\begin{array}{l}\text { \# Previous Manitoba } \\
\text { Records }\end{array}$ & Observer(s) \\
\hline Prothonotary Warbler $(1 \hat{\delta})$ & $03-06$ & Winnipeg & 2 accepted records & L. Cocks, m.o* \\
\hline Yellow-crowned Night-Heron (1) & 05 & Winnipeg & $19+$ previous records & A. Aug* \\
\hline Trumpeter Swan $(1-5)$ & $6-30$ & Pinawa & rccent breeding ${ }^{9}$ & P. Taylor, m.o* \\
\hline White-faced lbis (6) & $6-$ & Oak Hammock & recent breeding ${ }^{2}$ & G. Grieef, S. Grieef \\
\hline Snowy Egret (1) & 10 & St. Adolphe & $\begin{array}{l}\text { increasingly regular at } \\
\text { Whitewatcr Lake }\end{array}$ & $\begin{array}{l}\text { A. Courcelles, J. Bell, } \\
\text { m.o }\end{array}$ \\
\hline Whooping Crane (1 immature) & $10-$ & St. Adolphe & former breeder & C. Stevens, m.o* \\
\hline Lark Bunting ( 1 q) & 19 & Oak Hammock & irruptive, has bred & $\begin{array}{l}\text { D. Swayze, G. } \\
\text { Machnee* }\end{array}$ \\
\hline Eurasian Collared-Dove $(1+)$ & 22 & Lyleton & present in 2005 & K. de Smet, m.o* \\
\hline Black-necked Stilt (2 pairs) & $22-$ & Whitewater Lake & 7 previous records & K. dc Smet, m.o* \\
\hline Red-bellied Woodpecker $(1 \delta)$ & 23 & Sclkirk & $>30$ records, has bred? & N. Massey* \\
\hline Green Heron (1) & 24 & Winnipcg & $\sim 100$ records, has bred & A. Ens, m.o \\
\hline Snowy Egrct (1) & 25 & near The Pas & $\begin{array}{l}\text { increasingly regular at } \\
\text { Whitewater Lake }\end{array}$ & E.Bouvicr, B.Pillipow* \\
\hline Yellow-billcd Cuckoo (1) & $27-28$ & Winnipeg & 21 records, has bred & B. Carey, $11 . o^{*}$ \\
\hline Black-hcadcd Grosbeak $(10)$ & $30-$ & Melita & $>20$ records & K. de Smet, m.o* \\
\hline Little Blue Heron (1) & 31 & Whitewater Lake & $16+$ records & K. de Smet, m.o* \\
\hline
\end{tabular}


in the Tourond Creek area for over a month, the last sighting being on June 12 by George Holland and Heather Laird. More than 150 people delighted in observing this magnificent bird (Larry de March, pers. comm.). This is the second time in recent years that an immature Whooping Crane has (partially) summered in Manitoba, the last being near Delta from June 14 to July 29, 1988. ${ }^{11}$ Two months later, an adult Whooping Crane spent August 13 - 18 associating with Sandhill Cranes in the area between Ashern and Moosehorn near Lake Manitoba (Albert Hochbaum and many observers). Since immature birds acquire an adult facial pattern by 350 days old, ${ }^{10}$ it is possible that this was the same bird as seen near St. Adolphe.
Manitoba was at the same time of year and along the same beach ridge in 1996. ${ }^{11}$ Seven Lark Buntings were reported from southwestern Manitoba in mid- to late May and an Eastern Meadowlark from the Sandilands area on May 26. There were also several interesting records just outside of the period considered here, including a Northern Mockingbird at Grand Beach on April 28, a male Harlequin Duck at Seven Sisters from June 2 to early August, a male Eurasian Wigeon at Oak Hammock on June 5, and a Yellow-billed Cuckoo near the Rat River Wildlife Management Area on June 6 (single observer).

\section{Weather (or not)}

The fact that so many extraordinary

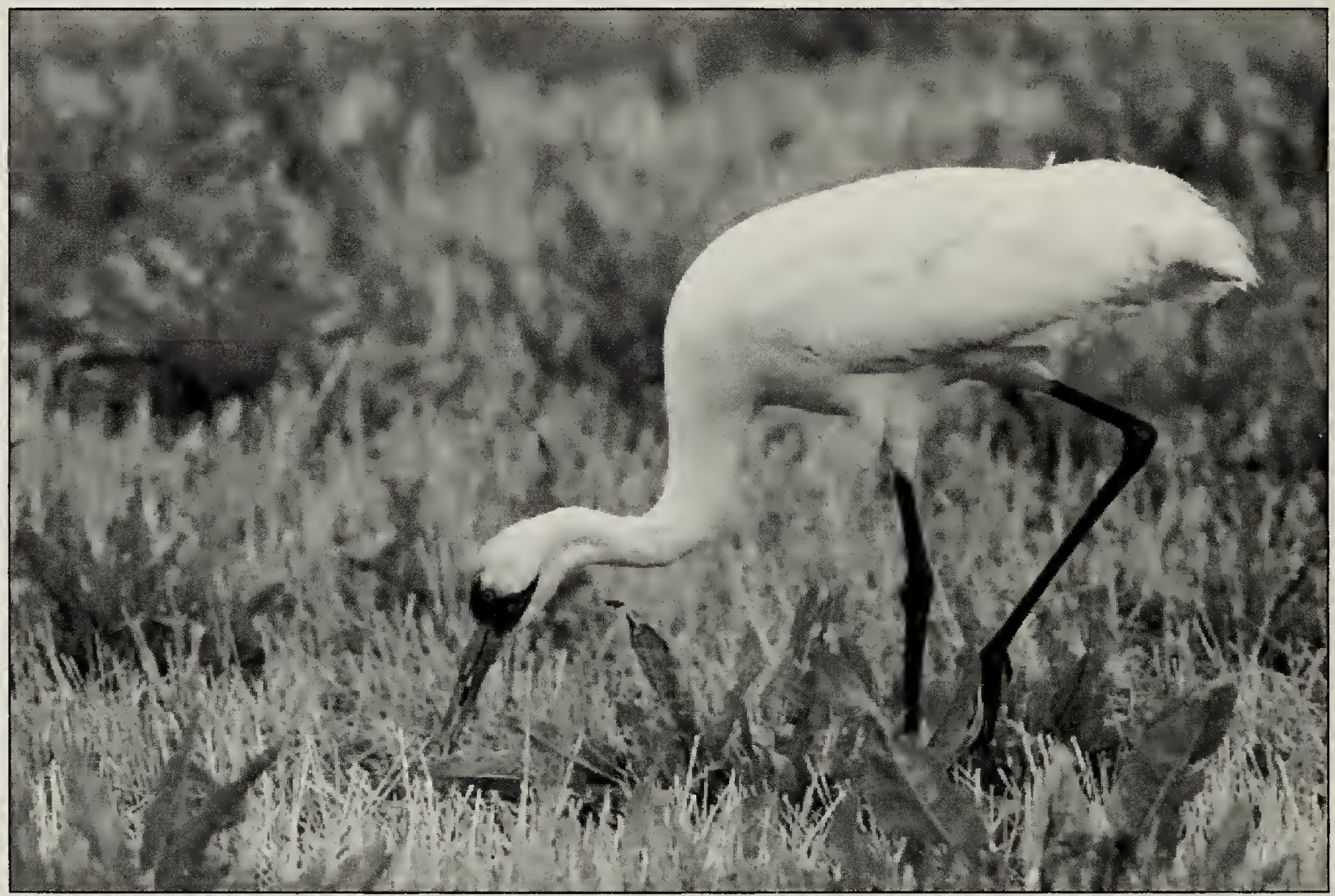

Figure 3. Immature Whooping Crane near Tourond Creek on May 15, 2006.

Christian Artuso

There were several single-observer reports which lack photographic documentation and must therefore be treated as hypothetical. The most noteworthy of these was a Worm-eating Warbler on May 30 at Delta. The only accepted record of this species in vagrants occurred within a short period of time suggests that weather phenomena may have been influential. Although the following discussion is speculative, it is worth commenting on some of the patterns in timing and distribution. The Yellow-crowned Night- 
Heron (Table 2), was found in the same area of the Fort Whyte Centre as the Prothonotary Warbler. These two species have similar northern limits to their breeding ranges along the flood plains of the upper Mississippi River in Minnesota, ${ }^{14,16}$ and their unlikely cooccurrence in Winnipeg might be linked to a weather event such as the low pressure system(s) that moved through central North America from April 28 to May $4 .{ }^{12}$ The $2000 \mathrm{~km}$ vagrancies of the Swainson's Warbler and Black Vulture were separated by a mere three days. The breeding ranges of these two species in the southeastern U.S.A are also somewhat similar, although the range of Black Vulture extends farther northeast along the eastern seaboard. ${ }^{1,4}$ These records coincide with a low-pressure system that moved northeast over Ontario and Quebec from May $6-8 .{ }^{12}$

\section{Acknowledgements}

I am grateful to Peter Taylor and Rudolf Koes for their assistance in compiling records and checking my accuracy. Larry de March, Ken De Smet, Stuart Houston, Bob Luterbach and two anonymous reviewers provided thoughtful comments which greatly improved this note.

1. BROWN, R. E., and J. G. DICKSON. 1994. Swainson's Warbler (Limnothlypis swainsonii). In The Birds of North America, No. 126 (A. Poole and F. Gill, eds.). Philadelphia: The Academy of Natural Sciences; Washington, DC: The American Ornithologists' Union.

2. BAZIN, R. and C. ARTUSO. 2006. First documented breeding record of White-faced lbis in Manitoba. Blue Jay 64: 64-68.

3. BOARDMAN, G. A. 1893. The Black Vulture in Dakota. Forest Stream 20: 106.

4. BUCKLEY, N. J. 1999. Black Vulture (Coragyps atratus). In The Birds of North America, No. 411 (A. Poole and F. Gill, eds.). Philadelphia: The Academy of Natural Sciences; Washington, DC: The American Ornithologists' Union.
5. CALDER, W. A. and L. L. CALDER. 1992. Broad-tailed Hummingbird. In The Birds of North America, No. 16 (A. Poole, P. Stettenheim, and F. Gill, eds.). Philadelphia: The Academy of Natural Sciences; Washington, DC: The American Ornithologists' Union.

6. CAMPBELL, R. W., N. K. DAWE, I. MCTAGGART-COWAN, J. M. COOPER, G. W. KAISER, A. STEWART, and M. C. E. MCNALL. 2001. The birds of British Columbia. Volume 4 Passerines, Wood-Warblers through Old World Sparrows. Vancouver: University of British Columbia Press.

7. CRINS, W. J. 2006. Ontario Bird Records Committee Report for 2005. Ontario Birds 24: 5474.

8. GODFREY, W.E. 1986. The Birds of Canada. Revised Edition. Ottawa: National Museums of Canada.

9. KOES, R. F., and P. TAYLOR. 2004. Prairie Provinces. North American Birds 58: 93-94.

10. LEWIS, J. C. 1995. Whooping Crane (Grus americana). In The Birds of North America, No. 153 (A. Poole and F. Gill, eds.). Philadelphia: The Academy of Natural Sciences; Washington, DC: The American Ornithologists' Union.

11. MANITOBA AVIAN RESEARCH COMMITTEE. 2003. The Birds of Manitoba. Winnipeg: Manitoba Naturalists Society.

12. NATIONAL OCEANIC AND ATMOSPHERIC ADMINISTRATION (U.S National Weather Service) daily weather map web page. http:// www.hpc.ncep.noaa.gov/dailywxmap/index.html

\section{NORTH DAKOTA BIRDING SOCIETY. Rarities Photo Gallery. http:// www.ndbirdingsociety.com}

14. PETIT, L. J. 1999. Prothonotary Warbler (Protonotaria citrea). In The Birds of North America, No. 408 (A. Poole and F. Gill, eds.). Philadelphia: The Academy of Natural Sciences; Washington, DC: The American Ornithologists' Union.

15. SMITH, A. R. 1996. Atlas of Saskatchewan Birds. Regina: Saskatchewan Natural History Society Special Publication 22.

16. WATTS, B. D. 1995. Yellow-crowned NightHeron (Nyctanassa violacea). In The Birds of North America, No. 161 (A. Poole and F. Gill, eds.). Philadelphia: The Academy of Natural Sciences; Washington, DC: The American Ornithologists' Union. 